\title{
BASIC PRINCIPLES OF LIABILITY FOR THE ACTS LEADING TO ENVIRONMENTAL DAMAGE*
}

\author{
D.-Ş. Paraschiv
}

\section{Daniel-Ștefan Paraschiv}

Faculty of Law, University Spiru Haret Bucharest, Bucharest, Romania

*Correspondence: Danel-Ștefan Paraschiv, Lecturer Professor Phd, Faculty of Law, University Spiru Haret, Bucharest, Ion Ghica Street, no.13, Bucharest, Romania

E-mail: bnp_daniel-stefanparaschiv@ @otmail.com

\begin{abstract}
The international community considers that one of the achieving means of the environmental protections consist in the liability for damages caused to the environment, yet the establishment of an international systematic regime of this type of liability is still a difficult thing to achieve, taking into account the diversity and complexity of problems which resides from committing multiple damages for the environment.
\end{abstract}

Keywords: environmental protection, pollutant, damages, liability, damage repair

\section{Introduction}

Due to the diversity of fields in which the liability acts for damaging acts, the boundaries of legislations and legal institutions are exceeded, representing a universal term, specific to the human society in its whole ${ }^{1}$.

Legal liability, is manifested as a severe form of social liability/responsibility, has a legal character, therewith it cannot exist without a legal ruling in regard to sanctioning some illicit behaviours, in the purpose of conservation of the relation and social values system ${ }^{2}-$ in the researched case, the defence of environmental values.

In environmental protection field the legal liability is triggered as a primitive measure against the ones who commit damaging acts to the ecological equilibrium ${ }^{3}$, in the purpose of sanctioning and re-education them, as well as for the establishment of rightful violated order ${ }^{4}$, respectively of the ecological equilibrium necessary for human life development and of other beings in proper conditions.

By violation of a legal normative from the environmental field, a legal liability report arises, that has a settlement of sanctioning the one guilty for committing such an illegal act, which in return insures the effectiveness of the right, maintaining social order and preventing behaviour, according to law 5 .

\footnotetext{
"This paper has been financially supported within the project entitled "Horizon 2020 - Doctoral and Postdoctoral Studies: Promoting the National Interest through Excellence, Competitiveness and Responsibility in the Field of Romanian Fundamental and Applied Economic Research", contract number POSDRU/159/1.5/S/140106. This project is co-financed by European Social Fund through Sectoral Operational Programme for Human Resources Development 2007-2013. Investing in people!

${ }^{1}$ Ladislau Lorincz, Mircea Străoanu, Răspunderea juridică, parte integrantă a răspunderii sociale, in ,Studii şi cercetări juridice”, nr. 1, 1970, p. 7-21.

${ }^{2}$ Nicolae Popa, Teoria generală a dreptului, Bucharest University Publishing house, 1992, p. 281.

${ }^{3}$ Active topics illegal acts committed in violation of the rules of law are at home, people, their conduct unlawful in that context with different causes and manifestations nuanced (See Nicolae Popa, [2] , p . 280 ) .

${ }^{4}$ Sofia Popescu, Fundamentul răspunderii juridice. Câteva remarci, in „Studii de drept”, vol. 2, Publishing house Universitas Timisienses, Universitatea de Vest Publishing house, Timişoara, 1998, p. 74 and fol.

${ }^{5}$ Sofia Popescu, Teoria generală a dreptului, Lumina Lex Publishing house, Bucharest, 2000, p. 299.
} 
Arisen in the affirming content of the environmental particularities right and of need of a proper response to the prevention and repair of the ecological damage, the environmental liability has a distinctive legal nature, with borrowings from other forms of legal liability, but also with irreducible features to them, configuring a distinctive status and an own content ${ }^{6}$.

\section{Specific principles of legal liability in the environmental field}

The liability for acts that affect the environment are delimited by other forms of legal liability which are traditional through a series of characteristics, yet until present time the specialty doctrine did not study systematically the specific principles which sit on the basis of this form of liability.

- Firstly, we find that this is not, mainly, a punitive liability but one of a patrimonial type, determined by the risk of appearance or existence of damages brought to the environment, which constitutes the institutional mean of promoting and achieving specific overcoming/prevention mechanisms and of repair to specific damages. Also, the main purpose of the liability in the environmental field, in general, consists in the ceasing of damaging activities and recovering the done damages.

- A series of elements of the its legal regime is somewhat linked to the civil liability, yet in many ways the civil regime is completed by the public one, thus insuring the full repairing of damages brought to the environment ${ }^{7}$; its public character comes from major attributions awarded to „competent authorities" for the identification of the one who provoked the ecological damage and insuring the legal means of prevention and repair.

- The specific principle situated at the basis of the legal liability in the environmental field is that the ,pollutant pays”, consecrated differently by national legislations and international texts, being inspired from the economic theory, according to which the external social expense which is followed by the industrial manufacturing needs to be internalized, meaning taken into account by business operators for establishing the production expenses, it being expressed initially and fundamentally in a legal way at an European level, but reaches out to achieve a universal gratitude and consecration . $^{8}$

Widely, the principle sees the imputation of the manufacturer of the social expense of pollution for which it generates, thus determining the trigger of a liability mechanism for ecological damages which needs to cover all aspects of a pollution, not only over the goods but also for the people, and over the nature itself (in these economic terms the liability is expressed through the notion of internalizing external expenses or the theory of externalizations $)^{9}$.

Also, in essence, the principle of ,polluter pays” is one of economic principle, which sees to allocate by the manufacturer of pollution expense and of damages brought to the environment, supported by the public authorities ${ }^{10}$.

This principle was consecrated officially for the first time by the Organization of Economic Cooperation and Development (OECD), which included it, starting with the 70s in a series of recommendations, as: Recommendation C(72) 128 from 1972 regarding the directive principles referring to the international economic aspects of environmental policies, Recommendation C(74) 223 from 1974 regarding the implementation of the principle the

\footnotetext{
${ }^{6}$ Mircea Duţu, Introducere în dreptul penal al mediului (Introduction to Environmental Criminal Law), Hamangiu Publishing house, Bucharest, 2013, p. 101.

${ }^{7}$ Public liability scheme has some restrictions regarding the application (type of environmental damage, types of activities that affect them), character (strict liability only in certain cases), enlargement (civilian and unlimited liability limits public when it is objective).

${ }^{8}$ Michel Prieur, Droit de l'environnement, Dalloz Publishing house, Paris, 1991, pp. 170-181; P. Girod, La reparation du domage ecologique, LGDJ, Paris, 1974, pp. 84-91.

${ }^{9}$ Mircea Duţu, Tratat de dreptul mediului, Edition 3, C.H. Beck Publishing house, Bucharest, 2007, pp. 271 and next.

${ }^{10}$ Patricia W. Birnie, Alan E. Boyle, International law and the environment, Second edition, Oxford University Press Inc., New York, 2002, p. 92.
} 


\section{D.-Ş. Paraschiv}

polluter pays, Recommendation C(89) 88 from 1988 regarding the appliance of the principle the polluter pays to the accidental pollutions.

Internationally the principle „polluter pays" was stated in The Stockholm statement from 1972 (principle 21), and again in The Rio de Janeiro statement from 1992 (principle 2), as well as in other international legal instruments, as for example: The Geneva Convention regarding the atmospheric pollution on long distances, from 1979; The convention seeing the right of Montego Bay seas, from 1982 (art. 194 pct. 2); Convention regarding the cooperation for the durable protection and use of the Danube river, from Sofia, from 1984 (art. 2 par. 4) etc.

At start, the principle ,the polluter pays" taking into account the issue of supporting generated expenses by preventive measures for the protection of environment, which need to be reflected in the goods and services expenses caused by pollution over the production time and/or consumption", according to the Recommendation OECD C(74)223, without referring to the measures expenses regarding ex post facto.

The pollution generators supporting directly diminished expenses, due to execution of pollution prevention expenses only (equipping with devices and filtrations, technology adaptation etc.), while the society as a whole supports, immediately or in time, costs regarding the diminishing of negative effects of pollution of human health, generated by economic and social activities, which alter the environment as a whole.

To correct a such inequitable situation, the expenses of ,externalizations” needed to be „internalized" by legal recognition of the principle ,polluter pays", which was developed, afterwards considering that the polluter needs to support not only the costs for prevention measures but also for the reparatory measures; in this way OECD recommended that, besides expenses for the taken measures to overcome and control petrol spills at sea, to be taken into account the expenses regarding ,reasonable reparatory actions”, which need to be supported by the polluter (Recommendation $\mathrm{C}(81) 32$ ).

The principle also consist in 2 aspects: 1 preventive, representing the internalization of external social expenses (theory of externalizations) and 2 reparatory, according to which the one that cause a pollution is in owe to repair the done damage ${ }^{11}$.

In 1989 OECD extended the appliance of this principle, including in the task of the polluter the accidental pollution expenses, which needed to be found in the schemes regarding expense allocations for the pollution prevention and control.

As initially adopted, the principle did not cover border pollution or the possible ecological issues of the developing countries, thus the extent was imposed regarding the allocation of these costs, to keep the pollution under control ${ }^{12}$.

Ruling this principle is different in national state legislations, member of EU or of $\mathrm{OCDE}^{13}$.

This principle was incorporated in the EU legislation through unique European document from 1987 (art. 130R) and then through the treaty from Maastricht from 1992 (art. 130R.2 and art. 130S.5), being mentioned in the treaty from Amsterdam from 1997. An appliance of the principle is founded in the Council Regulation no. 1013/2006 regarding the supervision and control of waste transportation within, in and outside EC (published in JOUE no. L190 from 12 July 2006). Likewise, this represents the fundament of the directive 2004/35/EC, regarding civil liability seeing the prevention and repair of the damage caused to the environment.

In the right of EU the notion of ,polluter" was defined in the Council Recommendation EC from 7 November 1974, as being, ,the person who directly or indirectly causes damage to the environment or creates the conditions which lead to a damage".

\footnotetext{
${ }^{11}$ Monica-Elena Oțel, Răspunderea internaţională în domeniul mediului, Tome 3, Universul Juridic Publishing house, Bucharest, 2009, pp. 27 and fol.

${ }^{12}$ Daniela Marinescu, Tratat de dreptul mediului, All Beck Publishing house, Bucharest, 2003, p. 54.

${ }^{13}$ Mircea Duţu, Dreptul mediului, Edition 3, C.H. Beck Publishing house, Bucharest, 2010, p. 119.
} 


\section{BASIC PRINCIPLES OF LIABILITY FOR THE ACTS LEADING TO ENVIRONMENTAL $D A M A G E$}

The principle has a reduced efficiency, therewith in present time is mainly a convenient way to finance policies of environmental kind, and less a legal instrument which needs to obligate the one responsible to assume the consequences harmful to the environment.

In case of indetermination to individual liability, the principle has a right of consequence in imposing to certain industries to support the global liability of expenses for antipollution struggle.

Establishment of a causing linkage between the pollutant activity and the done damage needs to become on from the conditions of put in practice of the principle ,polluter pays", also, taking into account the particularities of the field, there cannot be the discussion of a certitude causality, thus, it can be accepted a probable existence of eminent.

Mainly, the principle suggests that the pollution needs to be imputable to a business operator, which needs to be designated as payer, therewith the national budget never needing to support the environmental caused damage expenses through private activities.

- Another principle, from the general one of the international public right regarding the liability of states for which illicit international acts, is the one of state liability for ecological damages done due to international violation of liabilities.

It has been stipulated explicitly or indirectly in different international texts as well as in some national regulations. Thus, for example, principle 21 of Stockholm statement foresees that the states have the liability to do such so the activities under their jurisdiction or control not to cause environmental damages to other states or common areas situate outside. Likewise, in the treaty concluded between Holland and RF Germany, at 8 April 1960 foresees that each of the contracting parties is liable to protect the waters against pollution and will be responsible for the caused damages due to the disrespect of this liability. At national level, for example art. 31 from Framework Bulgarian law from 1991 regarding environmental protection refers to the necessity to diminish harmful effects of border pollution and foresees their repairs based upon a treaty or in lack of it, according to general rules of the public international right.

The specialty doctrine has accepted, mainly, the principle of state liability for ecological border damages, but in practice there were few registrations of such complaints, situation which is due to problems generated from long and difficult international procedures regarding the administration of proofs, amplified by special circumstances which rise a series of specific aspects in settling the legal department on environmental themes, as well as determining the guilt degree or of legal necessary basis for the establishment of the liability.

- Related to this principle is the one on the holder right to invoke the international responsibility for harmful acts to the environment, which is usually the injured state in its rights by the wrongful act or was otherwise affected by that act $^{14}$.

Another state may invoke the responsibility of a guilty state, that state not acting as injured, but as a member of a group of states from which there is no violated obligation, the fundament of this act consisting by collective obligations, meaning those obligations which protect collectively an interest or interests of the international community as a whole.

There is even the possibility that a state, several or all states parties to the convention have incentive to plead guilty state responsibility, even if none of the requesting Member has not been particularly affected by the wrongful act - a situation that has regard to the obligations erga omnes.

Invoking state responsibility for acts harmful to the environment requires certain measures that have a relatively formal character, such as for example, the submission of a request by another state (or another state) or the commencement of proceedings before an international court; a protest or criticism of a state does not mean that the State has submitted the protest or criticism of liability to the State concerned.

\footnotetext{
${ }^{14}$ Monica-Elena Oţel, [11], pp. 121 and fol.
} 


\section{D.-Ş. Paraschiv}

- Action for certain damages caused to the environment can be engaged and on the basis of strict liability, negligence independent, which is used to recover damages by making a polluting human activities.

The possibility of recovering damages liability under " character objective, independent negligence " only requires the victim to prove the damage and the causal link between the act and the damage, removing the obstacle of proof of fault - particularly difficult in organic matter, due to the need of investigations involving the discovery and identification of the precise source of the damage, which requires some cooperation from the polluter.

Following establishment of this principle, the evidence of guilt is unnecessary for liability, so that environmental quality assurance obligations no longer belongs to the middle class, but becomes one by the result. In these circumstances will interest the final result, not only the diligence exercised to avoid pollution or environmental degradation.

- Environmental law establishes a strict liability derived from the law, starting from the fact that there are numerous technical and administrative regulations and requirements that must be met in activities so that non-compliance is sufficient for liability to be established.

Researching home situations on strict liability laws, we find that there are some environmental tort regimes specialized regulated by law, such as those regarding nuclear damage (Law no. 703/2001 on Civil Liability for Nuclear Damage ${ }^{15}$ ) or ship owners' liability for any damage resulting from the discharge of polluting hydrocarbons (Brussels Convention of 29 November 1969 on Civil Liability for Oil Pollution Damage) ${ }^{16}$, amended by the London Protocol of 27 November 1992 (CLC 1992).

\section{Conclusions}

Along with the principles set out in environmental law may be other specific basic rules of liability for acts affecting the ecological balance.

Liability for environmental damage - just ecological damage to persons or property damage caused by environmental pollutants, harmful actions and disasters - it can hold essentially that they can be recovered through : torts , under the Civil Code , as based on the " polluter pays " ( liability for the acts of its own, based on guilt, fault liability, the act of things, liability for abnormal disorders neighbourhood) Member liability for acts affecting environmental liability environmental objectives (covered by Directive no. 2004/35 / EC , transposed into Romanian Government Emergency Ordinance no. 68/2007 and art. 95 of Government Emergency Ordinance no. 195/2005) and strict liability derived from the law.

Each of the forms of liability requires its own rules of engagement and achievement. Thus, besides the specific mechanism to prevent and repair environmental damage, can be held liable polluter based on different legal foundations, the victim having the right to choose between liability for negligence, liability for the acts or the specific work of neighbourhood disorder ${ }^{17}$.

A correct and efficient implementation of forms of liability requires accurate delineation of the field of action, making correlations and completions needed and their integration as far as possible, within a system of principles, so the responsibility to be as complete and appropriate damages incurred in connection with the environment ${ }^{18}$.

\section{Bibliographic references}

\footnotetext{
${ }^{15}$ Published in the Official Gazette, Part I, no. 818 of 19 December 2001, as amended and supplemented.

${ }^{16}$ Ratified by Romania through Government Ordinance no. 15/2000, published in the Official Gazette, Part I, no. 35 of 29 January 2000.

${ }^{17}$ Each of these actions is autonomous, the applicant is asked to judge which way is most appropriate procedural conditions and adequate concrete nature of his injury.

${ }^{18}$ Mircea Duţu, [6], pp. 103 and fol., which also uses the notion of ,environmental damage” and the concept of ,ecological damage”.
} 
1. Mircea Duţu, Introducere în dreptul penal al mediului (Introduction to Environmental Criminal Law), Hamangiu Publishing house, Bucharest, 2013;

2. Mircea Duţu, Dreptul mediului, Edition 3, C.H. Beck Publishing house, Bucharest, 2010;

3. Monica-Elena Oţel, Răspunderea internaţională în domeniul mediului, Tome 3, Universul Juridic Publishing house, Bucharest, 2009;

4. Daniela Marinescu, Tratat de dreptul mediului, All Beck Publishing house, Bucharest, 2003;

5. Patricia W. Birnie, Alan E. Boyle, International law and the environment, Second edition, Oxford University Press Inc., New York, 2002;

6. Mircea Duţu, Tratat de dreptul mediului, Edition 3, C.H. Beck Publishing house, Bucharest, 2007Sofia Popescu, Teoria generală a dreptului, Lumina Lex Publishing house, Bucharest, 2000;

7. Sofia Popescu, Fundamentul răspunderii juridice. Câteva remarci, in „Studii de drept", vol. 2, Publishing house Universitas Timisienses, Universitatea de Vest Publishing house, Timişoara, 1998; 1992;

8. Nicolae Popa, Teoria generală a dreptului, Bucharest University Publishing house,

9. Michel Prieur, Droit de l'environnement, Dalloz Publishing house, Paris, 1991;

10. P. Girod, La reparation du domage ecologique, LGDJ, Paris, 1974;

11. Ladislau Lorincz, Mircea Străoanu, Răspunderea juridică, parte integrantă a răspunderii sociale, in „Studii şi cercetări juridice”, nr. 1, 1970. 


\section{D.-Ş. Paraschiv}

